\title{
Geochemical and petroleum characterization of the region of Zaghouan (Northeast Tunisia)
}

\author{
SOLTANI $\mathrm{H}^{1}$., MABROUK EL ASMI A ${ }^{1}$., BEL HAJ \\ MOHAMED A ${ }^{2} \&$ SAIDI ${ }^{2}$
}

${ }^{1}$ University of Science of Tunis, faculty of Science of El Manar (Corespandant e-mail: soltani3hassen@gmail.com)

${ }^{2}$ Entreprise Tunisienne d'Activités Pétrolières

An organic geochemical study vtaregeted M'Cherga (Valanginian-Barremian), Bahloul (upper Cenomanian-Lower Turonian) and the Bou Dabbous (Ypresian) formations, outcropping in the Zaghouan area (northeast of Tunisia). The study used specific analyses based on Rock Eval pyrolysis and the GC-MS techniques. In addition, five oil indices collected from the Abiod, Aleg and Bou Dabbous formations, were also analyzed by Gas Chromatography coupled to Mass Spectrometry.

The M'Cherga Formation is rich in marine-dominated organic matter; it has reached the oil-window stage (mature), and can therefore constitute an average-to-good-quality source rock. The Bahloul Formation is rich in organic matter with a marine origin (type II), immature to marginally mature. The Bou Dabbous Formation, outcropping at Jebel el Guebli is characterized by a moderate richness of organic matter of type II / III but it is mature with Tmax values averaging $449^{\circ} \mathrm{C}$.

The oil seeps-oil seeps correlation allowed the subdivision of the oil seeps into two large families using the Past3 software. The first family consists of samples of oil seeps associated with the Abiod and Aleg formations. The second family includes the oil seep associated with the Bou Dabbous formation.

The oil seeps-source rock correlations (Past3) indicate that the oil seeps found in the Abiod and Aleg formations are generated by the Bahloul formation while the Bou Dabbous Formation oil seep was generated by the same rock.

The modeling by the GENEX software shows that the M'Cherga, Fahdene and Bou Dabbous source rocks at the P1 well, drilled not far from the study area, have all started to generate hydrocarbons since the Santonian, Campanian and Tortonian respectively. Nevertheless, only the M'Cherga Formation began to expel its hydrocarbons since the Pliocene 